\title{
Severe Encephalitis in Infant with COVID-19: A Case Report
}

\author{
Aspazija Sofijanova $^{1 *}$, Sonja Bojadzieva ${ }^{2}$, Filip Duma $^{3}$, Elizabeta Shuperliska ${ }^{1}$, Avdi Murtezani $^{2}$, Olivera Jordanova ${ }^{4}$ \\ ${ }^{1}$ Department of Intensive Care Unit, University Children's Hospital, Ss Cyril and Methodius University, Skopje, Republic of Macedonia; \\ ${ }^{2}$ Department of Gastroenterology, University Children's Hospital, Ss Cyril and Methodius University, Skopje, Republic of Macedonia; \\ ${ }^{3}$ Department of Neurology, University Children's Hospital, Ss Cyril and Methodius University, Skopje, Republic of Macedonia; \\ ${ }^{4}$ Department of Clinical Laboratory, University Children's Hospital, Ss Cyril and Methodius University, Skopje, Republic of Macedonia
}

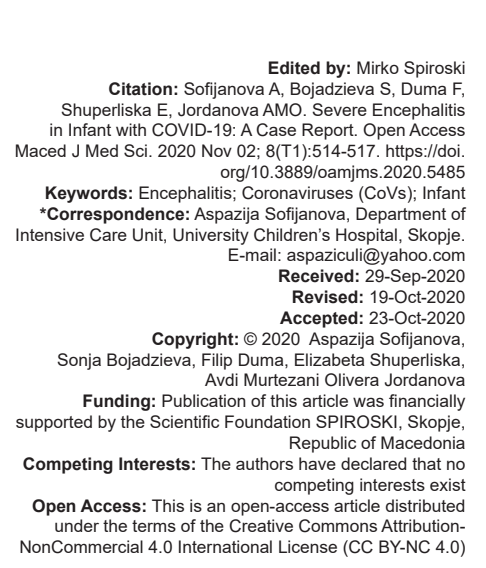

Abstract

BACKGROUND: Encephalitis is a serious condition that contains neurological dysfunction cause by inflammation of the brain tissue. Etiological factors for the occurrence of this condition include infectious and non-infectious causes.

CASE REPORT: We are presented 9-month-old infant referred to our clinic in convulsive status, fever, and disturbed consciousness. From anamnestic information, the infant has been febrile for 2 days with profuse vomiting initiating just before admission at the clinic. At the moment of admission in the clinic, the infant looked intoxicated with generalized tonic-clonic seizures, with shortness of breath and fever with a weakened reaction to painful stimuli. It was admitted in the Isolation Unit by the protocol of the clinic. Laboratory investigations were done. Due to the persistence of convulsive status, a computed tomography scan of the brain was performed with the finding of enlargement of the lateral ventricles, with intraventricular masses and pronounced internal hydrocephalus. The results of severe acute respiratory syndrome coronavirus 2 (SARS-COV-2) from the infant were positive as well as the grandmother. The infant was intubated immediately and put on mechanical ventilation SIPPV.

CONCLUSION: Our case report could suggest that SARS-CoV-2 infection may cause severe clinical symptoms neurological manifestations, and encephalitis in infants.

\section{Introduction}

Encephalitis is a serious condition that contains neurological dysfunction cause by inflammation of the brain tissue [1]. Etiological factors for the occurrence of this condition include infectious and non-infectious causes [2], [3]. The exact cause of this condition is often unknown, but the most common causes of infection are viruses. The viruses that can cause encephalitis include VaricellaZoster virus, Epstein-Barr virus, Herpes simplex virus (type 1 and 2), enteroviruses, Rubeola, West Nile virus, and Rabies [2], [4]. Encephalitis can also be caused by a bacterial infection such as tuberculosis, syphilis, Lyme disease, or after an infection caused by parasites such as toxoplasmosis [5]. Noninfectious causes include an autoimmune reaction in the body and this occurs when the body's own immune system produces antibodies against brain tissue [6]. Diagnostic tests required to confirm the diagnosis include: Blood tests, BAL or sputum, urine and stool tests, electroencephalography, lumbar puncture, X-ray, computed tomography (CT) scan, and magnetic resonance imaging [7], [8]. Treatment of viral encephalitis consists of antiviral drugs, supportive therapy such as monitoring of cardiac and respiratory function and respiratory support, intravenous fluids, anti-inflammatory drugs, and anticonvulsant drugs [9], [10], [11].

Human coronaviruses (CoVs) can be found in human population, and they can cause respiratory, enteric, hepatic, and neurological diseases [12], [13]. A novel CoV first time appears in December 2019 in Wuhan, Hubei province of China, with severe pneumonia causes [14]. Severe acute respiratory syndrome CoV 2 (SARS-CoV-2) is the third human CoV known to co-opt the peptidase angiotensin-converting enzyme 2 (ACE2) for cell entry [15]. SARS-CoV-2 cell entry is dependent on its $180-\mathrm{kDa}$ spike (S) protein, which mediates two essential events: Binding to ACE2 by the amino-terminal region and fusion of viral and cellular membranes through the carboxyl-terminal region [16]. Infection of lung cells requires host proteolytic activation of the spike at a polybasic furin cleavage site [17]. The lung pathology in severe disease is different from the earlier pneumonitis, with progressive loss of epithelialendothelial integrity, septal capillary injury, and marked neutrophil infiltration, with complement deposition, intravascular viral antigen deposition, and localized intravascular coagulation [18]. The virus binds to the ACE2 receptor, located in epithelium of the small 
intestine, respiratory tract, kidney cells, respiratory tract, the vascular endothelium throughout the body, and widely throughout the central nervous systems. ACE2 receptor is expressed in astrocytes, oligodendrocytes, neurons and concentrated in ventricles, and posterior cingulate cortex, olfactory bulb, substantia nigra, and middle temporal gyrus. Most patients with SARS-CoV-2 manifest a respiratory infection followed by sore throat cough, fatigue, shortness of breath, and respiratory distress. In addition to these effects on organic systems, larger studies published by China and France show that as many as $36 \%$ of patients with this infection develop neurological symptomatology. SARS-CoV-2 can cause a wide range of symptoms from other organic systems such as the gastrointestinal tract, manifested by diarrhea and vomiting, blood clotting disorders, and heart damage [19], [20], [21].

Organ dysfunction can be life-threatening. Rapid clinical symptom in pediatric patients infected with SARS-CoV-2 and neurological damage may lead to endotracheal intubation and placement of this group of patients on mechanical ventilation [22], [23], [24].

\section{Case Report}

We are presented 9-month-old infant referred to our clinic in convulsive status, fever (temperature 38.2), and disturbed consciousness. From anamnestic information, the infant has been febrile for 2 days with profuse vomiting initiating just before admission at the clinic. Epidemiological survey for COVID-19 was a false negative. At the moment of admission in the clinic, the infant looked intoxicated with generalized tonic-clonic seizures, with shortness of breath and fever with a weakened reaction to painful stimuli. It was admitted in the isolation unit by the protocol of the clinic. The seizures were treated with an intravenous benzodiazepine. The test of SARS-CoV-2 was done. Laboratory investigationes were made: Complete blood count: Hemoglobin $=105 \mathrm{~g} / \mathrm{l}$, erythrocytes $=4.45$ $\times 10 * 12 /$, leukocytes $=10.69 \times 10 * 9 / /$, thrombocytes $=242 \times 10^{*} 9 / \mathrm{l}$, hematocrit $=31.8 \%$, neutrophils $=$ $45.5 \%$, lymphocytes $=43.5 \%$; C-reactive protein $=$ $<0.2 \mathrm{mg} / \mathrm{l} ;$ glycemia $=13.46 \mathrm{mmol} / \mathrm{l}$; sodium $=133$ $\mathrm{mmol} / \mathrm{l}$, potassium $=4.3 \mathrm{mmol} / \mathrm{l}$, calcium $=2.13 \mathrm{mmol} / \mathrm{l}$, phosphor $=1.72 \mathrm{mmol} / \mathrm{l}$, magnesium $=0.77 \mathrm{mmol} / \mathrm{l}$, chloride $=106 \mathrm{mmol} / \mathrm{l}$; total bilirubin = $1.8 \mathrm{umol} / \mathrm{l}$; direct bilirubin $=<1.8 \mathrm{umol} / \mathrm{l} ; \mathrm{AST}=54 \mathrm{U} / \mathrm{L} ; \mathrm{ALT}=29$ $\mathrm{U} / \mathrm{L} ; \mathrm{LDH}=314 \mathrm{U} / \mathrm{L} ; \mathrm{GGT}=10 \mathrm{U} / \mathrm{L} ;$ creatinine $=41$ umol/l; urea = 3,3 mmol/l; total protein $=56 \mathrm{~g} / \mathrm{l}$, albumin $=42 \mathrm{~g} / \mathrm{l} ; \mathrm{CK}=206 \mathrm{U} / \mathrm{L} ; \mathrm{CKMB}=49.12 \mathrm{U} / \mathrm{L} ; \mathrm{ABS}: \mathrm{pH}=$ 7.38; $\mathrm{pCO}_{2}=34.1 \mathrm{mmHg} ; \mathrm{pO}_{2}=90.5 \mathrm{mmHg} ; \mathrm{HCO}_{3}$ $=19.7 \mathrm{mmol} / \mathrm{l} ; \mathrm{BE}=-4.9 \mathrm{mmol} / \mathrm{l}$; and $\mathrm{sO}_{2}=96.1 \%$. Urinalysis parameters were normal. Due to suspected encephalitis, a lumbar puncture was indicated. We consult an ophthalmologist who performs fundus oculi examination and no changes were detected. We perform a lumbar puncture, liquor was obtained under pressure, clear, without elements, with proteinuria and glycorrhachia. Liquor biochemical analysis: Lactates $=1.70 \mathrm{mmol} / \mathrm{L}$, glucose $5.08 \mathrm{mmol} / \mathrm{L}$, and proteins = 2027 mg/L. Film array meningitis/encephalitis (ME) panel was not isolated from the liquor a causative agent. From blood culture was isolated Staphylococcus with film array blood culture identification panel qualitative multiplexed nucleic acid-based in vitro diagnostic test. The infant was put on dual antibiotic therapy with thirdgeneration cephalosporin and aminoglycoside, antiviral drug, anticonvulsant drug, and anti-edematous therapy. Due to the persistence of convulsive status, a CT scan of the brain was performed with the finding of enlargement of the lateral ventricles, with intraventricular masses and pronounced internal hydrocephalus (Figure 1).

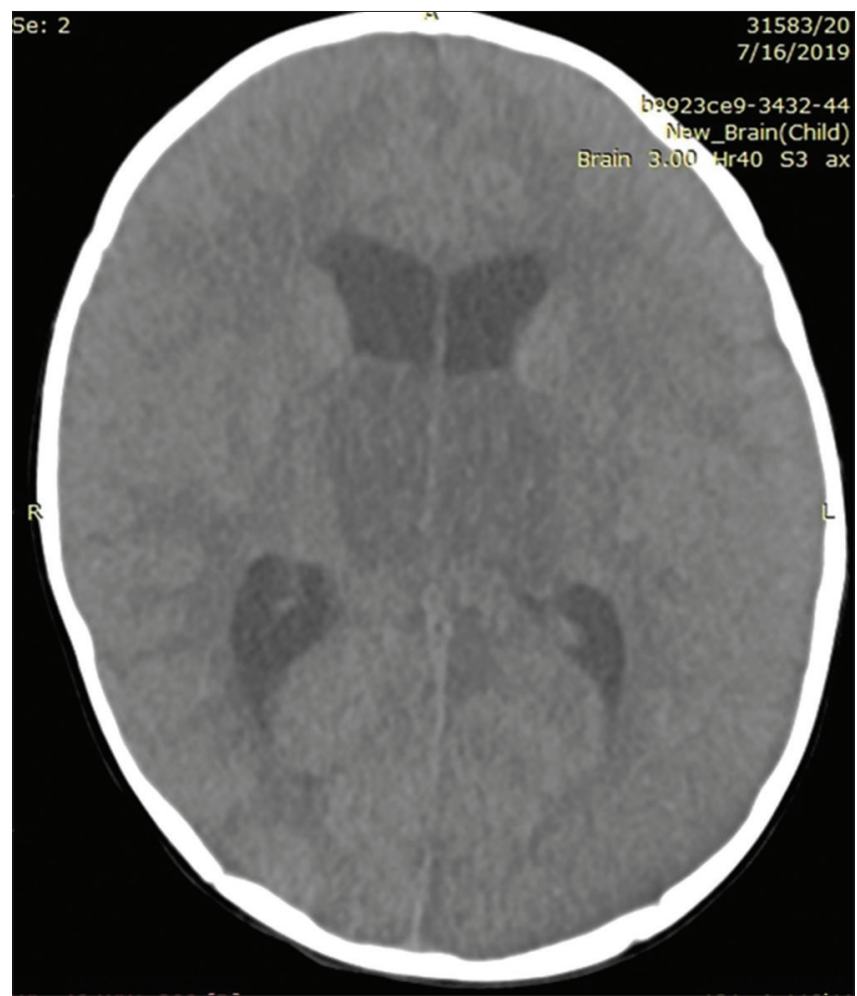

Figure 1: Computed tomography scan of the brain-enlargement of the lateral ventricles, with intraventricular masses and pronounced internal hydrocephalus

Late that day we have gotten the results of SARS-COV-2 from the infant that was positive as well as the grandmother that has actually taking care of the infant during the past 2 weeks. We have made a teleconference with Geneva Children's Hospital due to the fact that the infant had Swiss citizenship. They suggested, according to the fact that they might transfer the infant in their country and come by fly ambulance, but before that to intubate. That actually happened immediately after a few minutes with cardiac arrest and no breathing. The infant was intubated immediately and put on mechanical ventilation SIPPV. After a couple of hours, the plane came and the child by all means of protocols for COVID-19 pandemic was transferred safely in Geneva. 


\section{Discussion}

By all means, infants are before getting encephalitis due to viral infection. Symptoms of viral encephalitis in infants usually start with mild flulike symptoms, such as fever, fatigue, weakness, headache, and aches in muscles or joints. The symptoms can be much more severe and include: Seizures, confusion, loss of sensation and paralysis, agitation or hallucinations, muscle weakness, loss of consciousness, and coma. In young children and infants, symptoms, and signs encountered: Tense fontanels, poor feeding, irritability, nausea, and vomiting [25]. Timely diagnosis and treatment are important because it is difficult to predict how encephalitis will affect each individual. Given the heterogeneity of the disease, epidemiological, laboratory, clinical, and radiographic examinations are required to make a diagnosis and prepare the therapeutical protocol. According to previous studies from around the world, more than a third of patients with SARS-CoV-2 develop neurological symptoms, convulsions, loss of sense of smell and taste, hallucinations, disorientation, confusion, movement disorders [26], [27], [28]. SARS-CoV-2 virus can result with: Encephalitis, brain edema, stroke, neurological disorder, and Guillain-Barré syndrome, where the immune system responds to SARS-CoV-2 infection with attacks nerve cells that lead to muscle weakness and paralysis [29], [30]. Once in the bloodstream, the brain barrier replicates and causes neurological involvement. Although most patients in the pediatric population are asymptomatic or have a mild clinical picture, in some of them, the clinical picture may deteriorate rapidly and lead to acute respiratory distress or respiratory failure. Some pediatric patients could occur severe clinical manifestations with myocardial injury or heart failure, hypoxic encephalopathy, coagulation dysfunction, shock, and acute kidney injury. In this case report, the fast-moving of the poor child health and aggressive progression of the disease with proven SARS CO2 19 virus we were absolutely engaged with the information of this child as having severe inflammatory reaction SIRS that progressively made meningoencephalitis affecting all areas of the brain (we could not predict how long it has been taken in the child body) because of poor information of the family but we suppose that it has probably taken longer than 2 days (with fever). Encephalitis is something that has made an infant in very bad condition and stops circulation and breathing [22], [23], [24]. Talking and sharing the experience with the colleagues from Swiss, we could have expected this to happen and we have performed all the procedures, including monitoring mechanical ventilation and drug therapy. No any specific drug for COVID-19 has been given.

\section{Conclusion}

In our study (in this case report study), we have presented 9-month-old infant with COVID19 encephalitis who was referred to our clinic in convulsive status, fever (temperature 38.2), disturbed consciousness, severe clinical symptoms, and CT scan of the brain with the finding of enlarge lateral ventricles, intraventricular masses, and internal hydrocephalus. Our case report could suggest that SARS-CoV-2 infection may cause severe clinical symptoms, neurological manifestations, and encephalitis in infants.

\section{References}

1. Hancock B. Re: Public Health and Wellbeing Amendment (No Jab, No Play) Bill; 2015.

2. Kennedy PG. Viral encephalitis: Causes, differential diagnosis, and management. J Neurol Neurosurg Psychiatry. 2004;75(Suppl 1):i10-5.

PMid:14978145

3. Roos KL. Meningitis, encephalitis, brain abscess, and empyema. In: Harrison's Principles of Internal Medicine. New York: McGraw Hill Education; 2008. p. 2621-41.

4. Fisher DL, Defres S, Solomon T. Measles-induced encephalitis. QJM. 2015;108(3):177-82. https://doi.org/10.1093/qjmed/ hcu113

\section{PMid:24865261}

5. Larner AJ. Neuropsychological Neurology: The Neurocognitive Impairments of Neurological Disorders. Cambridge: Cambridge University Press; 2013. https://doi.org/10.1017/ cbo9781139176095

6. Armangue $\mathrm{T}$, Petit-Pedrol $\mathrm{M}$, Dalmau J. Autoimmune encephalitis in children. J Child Neurol. 2012;27(11):1460-9. https://doi.org/10.1177/0883073812448838 PMid:22935553

7. Venkatesan A, Tunkel AR, Bloch KC, Lauring AS, Sejvar J, Bitnun $A$, et al. Case definitions, diagnostic algorithms, and priorities in encephalitis: Consensus statement of the international encephalitis consortium. Clin Infect Dis. 2013;57(8):1114-28. https://doi.org/10.3410/f.718040335.793486207 PMid:23861361

8. Kneen R, Michael BD, Menson E, Mehta B, Easton A Hemingway $\mathrm{C}$, et al. Management of suspected viral encephalitis in children association of British neurologists and British paediatric allergy, immunology and infection group national guidelines. J Infect. 2012;64(5):449-77. https://doi. org/10.1016/j.jinf.2011.11.013 PMid:22120594

9. Ito $\mathrm{Y}$, Kimura H, Yabuta $\mathrm{Y}$, Ando $\mathrm{Y}$, Murakami T, Shiomi M, et al. Exacerbation of herpes simplex encephalitis after successful treatment with acyclovir. Clin Infect Dis. 2000;30(1):185-7. https://doi.org/10.1086/313618 PMid:10619751

10. Lewis P, Glaser CA. Encephalitis. Pediatr Rev. 2005;26(10):347.

11. Zekeridou A, Karantoni E, Viaccoz A, Ducray F, Gitiaux C, Villega $F$, et al. Treatment and outcome of children and adolescents with $\mathrm{N}$-methyl-D-aspartate receptor encephalitis. 
J Neurol. 2015;262(8):1859-66. https://doi.org/10.1007/ s00415-015-7781-9

PMid:25987208

12. Weiss SR, Leibowitz JL. Coronavirus pathogenesis. Adv Virus Res. 2011;81:85164.

PMid:22094080

13. Masters PS, Perlman S. Coronaviridae. In: Knipe DM, Howley PM, editors. Fields Virology. $6^{\text {th }}$ ed. Philidephia, PA: Lippincott Williams and Wilkins; 2013. p. 825-58.

14. Wang C, Horby PW, Hayden FG, Gao GF. A novel coronavirus outbreak of global health concern. Lancet. 2020;395(10223):4703. https://doi.org/10.1016/s0140-6736(20)30185-9 PMid:31986257

15. Andersen KG, Rambaut A, Lipkin WI, Holmes EC, Garry RF. The proximal origin of SARS-CoV-2. Nat Med. 2020;26:450-2. https://doi.org/10.1038/s41591-020-0820-9 PMid:32284615

16. Li F. Receptor recognition mechanisms of coronaviruses: A decade of structural studies. J Virol. 2015;89:1954-64. PMid:25428871

17. Hoffmann M, Kleine-Weber $H$, Pöhlmann S. A multibasic cleavage site in the spike protein of SARS-CoV-2 is essential for infection of human lung cells. Mol Cell. 2020;78:779-84.e5. https://doi.org/10.1016/j.molcel.2020.04.022 PMid:32362314

18. Magro C, Mulvey JJ, Berlin D, Nuovo G, Salvatore S, Harp J, et al. Complement associated microvascular injury and thrombosis in the pathogenesis of severe COVID-19 infection: A report of five cases. Transl Res. 2020;220:1-13. https://doi. org/10.1016/j.trsl.2020.04.007

PMid:32299776

19. Zubair AS, McAlpine LS, Gardin T, Farhadian S, Kuruvilla DE, Spudich S. Neuropathogenesis and neurologic manifestations of the coronaviruses in the age of coronavirus disease 2019 : A review. JAMA Neurol. 2020;77(8):1018-27. https://doi. org/10.1001/jamaneurol.2020.2065 PMid:32469387

20. Ye M, Ren $Y, L v T$. Encephalitis as a clinical manifestation of COVID-19. Brain Behav Immun. 2020;88:945-6. PMid:32283294

21. Wang HY, Li $X L$, Yan $Z R$, Sun $X P$, Han J, Zhang BW. Potential neurological symptoms of COVID-19. Ther Adv
Neurol Disord. 2020;13:1756286420917830. https://doi. org/10.1177/1756286420917830

PMid:32284735

22. CruzAT,ZeichnerSL.COVID-19inchildren: Initialcharacterization of the pediatric disease. Pediatrics. 2020;145(6):e20200834. https://doi.org/10.1542/peds.2020-0834 PMid:32179659

23. Dong $\mathrm{Y}, \mathrm{Mo} \mathrm{X}, \mathrm{Hu} \mathrm{Y}$, Qi X, Jiang F, Jiang Z, et al. Epidemiological characteristics of 2143 pediatric patients with 2019 coronavirus disease in China. Pediatrics. 2020;58(4):712-3.

24. Zimmermann P, Curtis N. Coronavirus infections in children including COVID-19: An overview of the epidemiology, clinical features, diagnosis, treatment and prevention options in children. Pediatr Infect Dis J. 2020;39(5):355-68. https://doi. org/10.1097/inf.0000000000002660

PMid:32310621

25. Thompson C, Kneen R, Riordan A, Kelly D, Pollard AJ. Encephalitis in children. Arch Dis Child. 2012;97(2):150-61. https://doi.org/10.1136/archdischild-2011-300100 PMid:21715390

26. Cascella M, Rajnik M, Cuomo A, Dulebohn SC, Di Napoli R. Features, Evaluation and Treatment Coronavirus (COVID-19). Treasure Island, FL: StatPearls Publishing; 2020.

27. Singhal T. A review of coronavirus disease-2019 (COVID-19). Indian J Pediatr. 2020;87(4):281-6.

PMid:32166607

28. Xia W, Shao J, Guo Y, Peng X, Li Z, Hu D. Clinical and CT features in pediatric patients with COVID-19 infection: Different points from adults. Pediatr Pulmonol. 2020;55(5):1169-74. https://doi.org/10.1002/ppul.24718 PMid:32134205

29. Gu J, Han B, Wang J. COVID-19: Gastrointestinal manifestations and potential fecal oral transmission. Gastroenterology. 2020;158(6):1518-9. https://doi.org/10.1053/j. gastro.2020.02.054 PMid:32142785

30. Mao L, Wang M, Chen S, He Q, Chang J, Hong C, et al. Neurological manifestations of hospitalized patients with COVID-19 in Wuhan, China: A retrospective case series study. JAMA Neurol. 2020;77(6):683-69. https://doi. org/10.1101/2020.02.22.20026500

PMid:32275288 